\author{
Barbara Kryk \\ University of Szczecin \\ e-mail: Barbara.Kryk@usz.edu.pl \\ ORCID: 0000-0003-1269-3142
}

\title{
THE 500+ FAMILY PROGRAM AND THE OBJECTIVE OF THE EUROPE 2020 LABOUR MARKET AREA
}

DOI: $10.15611 /$ pn.2020.9.06

JEL Classification: J01, J21.

\section{(C) 2020 Barbara Kryk}

This work is licensed under the Creative Commons Attribution-ShareAlike 4.0 International License. To view a copy of this license, visit http://creativecommons.org/licenses/by-sa/4.0/

Quote as: Kryk, B. (2020). The 500+ Family Program and the objective of the Europe 2020 labour market area. Prace Naukowe Uniwersytetu Ekonomicznego we Wrocławiu, 64(9).

\begin{abstract}
There is huge controversy around the issue of the impact of the 500+ benefit program on the labour market in Poland, especially on the professional activity of women. The effects in this area are not only relevant for the country but also for the European Union as a whole, as they determine the achievement of the employment goal of the Europe 2020 strategy. It was, therefore, decided to examine this issue more closely. The main goal of the article is to investigate how the 500+ benefit affects the supply of female labour force and the achievement of the employment target of the Europe 2020 strategy. The specific objectives: (1) what were the goals of the Polish government in the area of the labour market at the beginning of the implementation of the EU strategy, and what goals are currently in the Strategy for Responsible Development (SOR)? (2) what were the dynamics of female labour supply compared to the changes in the labour market? (3) what is the significance of the 500+ program for the trends in the labour market? (4) what loss (if any) for the economy resulted from the reduction of women's employment generated? The subject of the study is women's labour supply/employment, and the subject of research is the Polish economy. To achieve the study goals, the desk research method, time series and indicator analysis, and GDP gaps were used. The research period is 2010-2019, with particular emphasis on the period after the introduction of the benefit in 2016. The research conducted shows that adverse changes in the labour force supply of women caused by the $500+$ benefits, were offset by the return to the labour market of previously unemployed or inactive people. Thus, the strategic goal related to employment was achieved.
\end{abstract}

Keywords: labour market, women, Family 500+ programme, strategies Europe 2020. 


\section{Introduction}

One of the priority areas of the Europe 2020 strategy is inclusive growth, i.e. growth conducive to social inclusion, based on a high level of employment that ensures economic, social, and territorial cohesion. Such growth requires striving to professionally activate as many people as possible. Employment is treated as the most desirable way to counteract social exclusion. The strategy states that the employment of people aged 20-64 should increase so that in 2020 the employment rate reaches $75 \%$. Poland has adopted a slightly lower level of this indicator $-71 \%$. The value of this indicator has not been corrected in the 'Responsible Development Strategy' adopted in 2017, therefore it is still binding.

In Poland, the gradual improvement of the economic situation since 2010 has resulted in increased employment and reduced unemployment. Some concerns about further positive changes in this area were caused by the introduction of the Family $500+$ Programme in 2016. From the beginning, this programme was controversial because it was feared that it could cause negative changes in the labour market, especially among women of reproductive age, i.e. between 25 and 44 years of age, which would thereby prevent achieving the intended level of employment rate, that is, the fulfillment of EU obligations. For this reason, the main goal of the article was to check how the 500+ benefit affects the supply of female labour force and the achievement of the employment goal of the Europe 2020 strategy. In addition to this main objective, four specific sub-objectives were identified which are presented in the summary, together with the research methods used to achieve them.

There are several studies on the impact of the 500+ benefit, usually on female fertility and poverty. Among the available scientific publications, there are no such studies that take into account the impact of this benefit on the achievement of the Europe 2020 strategy objective in the field of employment. Therefore, this article fills the perceived research gap. In order to present the effects of the $500+$ benefit on employment, selected indicators related to this were analysed for the period 2010-2019 , with particular emphasis on the period after its introduction. This made it possible to draw conclusions about the degree of Poland's compliance with the EU commitment and the achievement of its own goals in this area.

\section{Theoretical aspects of the labour force supply of women with children}

The supply of labour force is a resource characterized by various spatial, inter-branch, temporal, or social mobilities. The causes and effects of the flows have, among others, the nature of the economic and institutional phenomena that are the subject of consideration of many economic theories describing phenomena occurring in the labour market. In Poland there were flows (inflow/outflow) of employees (women) in the labour market under the influence of $500+$, therefore in order to strengthen 
the theoretical phenomena, two selected theories of employment and labour market, taking into account employees' modes of behaviour, which according to the author are the most relevant to the topic of the article, were analysed.

The first of these is the neoclassical theory, in which the decision on the amount of work performed (expressed in full-time or number of working hours) is the effect of the optimization between consumption (income effect) and lost free time (substitution effect) (Samuelson and Nordhaus, 2020). Thus, women, like men, will evaluate (Hrynkiewicz, Witkowski, and Potrykowska, 2018):

- the attractiveness of available wages and the value of time away from work,

- whether the performance of professional work can generate deferred income (pensions) and of what amount,

- if they can receive income from work done in the household and of what amount,

- usefulness of time not spent at work, ways to change its value (e.g. staying at home with several children without having to pay for their care),

- whether the performance of work may affect the amount of income obtained outside it, in the form of social/maintenance payments (e.g. income per one family member determined to receive 500+ benefits for one child until 2019, and when this criterion was abolished, more women left their jobs).

In other words, women make decisions taking into account the utility function, in which income from work and outside of work shapes the level of consumption, and time outside it determines the income (benefits), consumption of goods and services produced in a household, and the satisfaction with time free from work and home responsibilities. Therefore, ultimately they choose the solution that is optimal for them at the given moment.

The second is the segmentation theory - an alternative to the neoclassical - in which the topic of labour mobility restrictions is an important element explaining the processes of creating and consolidating imbalances in the labour market (Dickens and Lang, 1992; Jarmołowicz and Knapińska, 2011; Knapińska, 2009; Reich, Gordon, and Edwards, 1973). This concept assumes the internal diversification of the labour market, which not only causes limited access to certain segments or their separation but also hinders the flow of labour force resources between them. The two most characteristic features of this concept are: (1) the labour market consists of at least two areas (dual theory), which are characterized by various conditions of wages, employment, and specific features offered to employees, and (2) there are periodic barriers to entry into the particular segments, resulting not only from the inadequate quality of job candidates but also from the limited demand of employers in relation to the number of people willing to be employed. In each segment, employers and employees operate on the basis of different rules of conduct (Doeringer, Piore, 1971; Piore, 2002). Therefore, the labour market is not uniform and consists of many markets with different structures and characteristics (Kryńska, 2000).

These two primary markets in segmentation theory are referred to as primary and secondary. The primary market includes well-paid, stable workplaces creating 
opportunities for job development/promotion, while the secondary market includes less prestigious, less well-paid workplaces, the number of which is determined by the economic situation. Access to the primary market is limited by the criteria required from employees such as education (e.g. higher, specialized), skills, or a specific experience necessary to perform the work. However, the second segment does not impose such restrictions, which is why some women, among others, due to less education, do not meet the criteria in the primary segment or have voluntarily chosen less prestigious jobs (social professions) for other reasons affecting their labour force supply (which are discussed later in this article), including childcare. It is also necessary to mention inequalities in the treatment of women in the labour market which are also evident in the amount of wages ${ }^{1}$; although Polish women are better educated, they still earn less. In general therefore, the unattractiveness of jobs in the secondary segment causes a large employee fluctuation, not only in terms of outflow to other employers but sometimes also into inactivity. Such decisions were made by some women in Poland after the introduction of the 500+ benefit.

The analysis shows that the theoretical basis for the functioning of the labour market takes into account the employee's right to decide on the choice of workplace, its nature, and being active or professionally inactive. Employment decisions are influenced by various conditions/factors and reasons. From an economic point of view, these may be, for example, "the usefulness of work in relation to leisure time" or "too low earnings" in relation to the income received from the 500+ benefit. Comparing the usefulness of work (its income) with the opportunity cost (taking care of children and living on income generated by the benefit) in the case of some Polish women, resulted in the decision to leave employment and be professionally inactive.

\section{Research methodology}

In order to achieve the goal of the study and answer the questions posed, the desk research method was used and three groups of variables were analysed: (1) activity rate by sex in the age group 20-64; the economic activity rate of women in selected age groups 25-34 and 35-44, the economic inactivity of women by reason; (2) the number of women employed by education, the number of employees by sex, the employment rate; (3) the number of unemployed persons by sex combined with the unemployment rate. This enabled the determination of the dynamics and trends of changes in the supply of female labour force against the background of market changes, estimation of the number of women who leave their jobs after the introduction of the $500+$ benefit, and the effects of this on the implementation of the strategic employment target, i.e. achieving the planned employment rate.

\footnotetext{
${ }^{1}$ According to CSO, Polish women earn $18.5 \%$ less than men.
} 
The final assessment of the impact of the Family 500+ parental benefit on the labour market was estimated by the loss in GDP due to women leaving the labour market. For this purpose, gross value added per employee was used.

\section{The $500+$ programme as a determinant of professional activity}

On April 1, 2016, the government programme "Family 500+" entered into force (Act of 11.02.2016), which introduced childcare benefit of PLN 500.00 per month for a child in the family. The purpose of providing childcare benefit is the partial coverage of expenses related to raising a child, including caring for him or her and satisfying their needs. Parental benefit is payable to either the mother, the father, or the child's actual guardian, or the child's legal guardian. The parental benefit is paid until the child is 18 years old. Initially it was granted to the second and subsequent children of anyone who submitted the application and to the first child of a family with an income below PLN 800 per family member, and PLN 1,200 for a family member caring for a child with a disability. Thanks to the introduced changes, from 1 July 2019, the benefit has been granted to all children up to the age of 18, regardless of the family's income. Financial support covered almost 6.5 million children, and the total sum allocated amounted to over PLN 102 billion (4. urodziny programu „Rodzina 500+", n.d.).

The introduction of the government programme "Family 500+" was intended to increase women's fertility and reduce poverty, especially among children, through financial support for raising children in Poland and strengthening the family (the benefit is treated as an investment in the family, one can say an investment in human capital). From the beginning the programme raised reservations as to the possibility of causing negative effects on the labour market, in particular among women of reproductive age, i.e. between the ages of 25 and 44 . Therefore, the author wished to check if these fears were well-founded. However, it should be remembered that the $500+$ benefit is not the only factor affecting the economic activity of women, there are others, and women's professional activity is a result of various conditions, not just one.

The factors affecting women's professional activity include (Report, 2016):

- Educational level - the higher this is, the greater the economic activity of women; usually, education positively affects their income, which is why such people are more motivated to work.

- Working conditions - the greater the discrimination against pay or/and the taxation of work, the lower the professional activity of women.

- Conditions for entrepreneurship - the more favorable these are, the greater the professional activity of women.

- Socio-cultural expectations - related to the preferred family model and the role of women in $\mathrm{it}^{2}$. The preferences in the "own family" model showed that the

\footnotetext{
${ }^{2}$ The traditional family model has become outdated in favour of the partner family model because double income is a condition of maintaining a fair standard of living for the family (Giddens, 2010).
} 
preferred model depends on the phase of family development. In the case of very young children (0-3 years), the majority of respondents prefer full-time work for men and partial or complete withdrawal of the woman from the job market. With the increase of the child's age, the acceptance of the mother's professional work increases and, therefore, the professional activity of women (Haponiuk, 2014; Kotowska, Sztanderska, and Wóycicka, 2007; Rękas, 2013).

- Number of children in the family - the higher the number, the lower the professional activity of women.

- Institutional solutions - availability of nurseries or kindergartens and regulations regarding maternity/paternity, or parental leave. The greater availability of institutional assistance has a positive impact on the professional activity of women. Since 2016, this assistance has also included the 500+ benefit, which was provided to not only perform a procreative function but also as a motivation to work by increasing the income of families obtained from working. It is known that the economic activity of women has a positive effect on income, and thereby on the living standards and household's well-being. This is due, among other things, to the fact that women promote different consumption patterns than men - research shows that women invest a larger share of household income in the education and health of their children (OECD, 2016). Unfortunately, not all women responded equally to the financial support offered; some of them left their jobs and this was not related to childbirth.

In context of the above, it can be said that the 500+ benefit alone, unlike any other single factor determining the economic activity of women, is insufficient to maintain levels of women's professional activity, and even more so for growth. It is necessary to provide women with development opportunities and access to education, appropriate working conditions and institutional support in order to be able to fully and effectively use their resources of talent, skills and experience. Only a comprehensive approach to the issue can have a synergistic effect in the form of the increased professional activity of women.

\section{Research analysis}

In the opinion of the general public, there is often an argument that parental benefit is demobilizing and causes the professional deactivation of women, which in turn may threaten the achievement of the employment goal, both in Poland (71\%) and in the EU (75\%). Therefore the analysis covered the period from the beginning of the Europe 2020 strategy, with particular emphasis on the period after the introduction of the 500+ Programme, i.e. after 2016.

First, the economic activity coefficient by sex in the age group 20-64 was analysed to check what changes occurred in the activity of women $(\mathrm{K})$ in relation to men $(\mathrm{M})$ after the introduction of the $500+$ benefit, taking into account the general population (Figure 1). The data shows that during the period under review the economic activity 


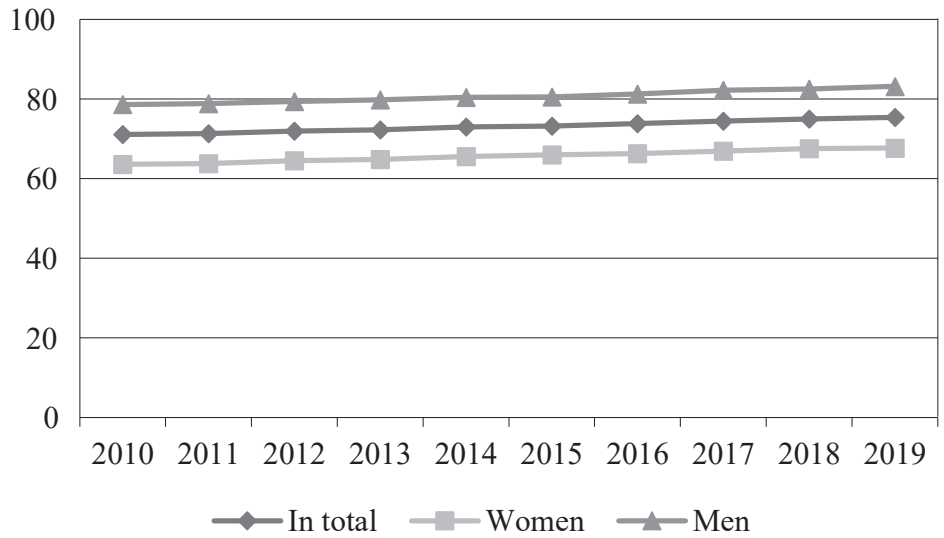

Fig. 1. Activity rate by sex at the age of 20-64 (\%)

Source: study based on Eurostat.

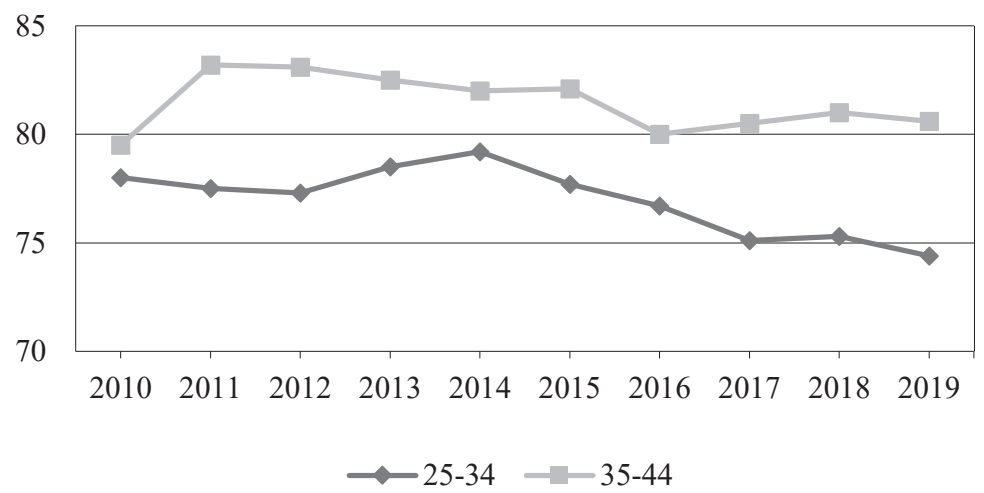

Fig. 2. Employment rate of women in selected age groups (\%)

Source: study based on Eurostat.

rate $(\mathrm{K})$ was on average $15 \%$ lower than the ratio $(\mathrm{M})$, but both showed an upward trend, even after 2016. This positively affected the aggregate economic activity rate, which also had an upward trend. One would, therefore, be entitled to think that nothing negative happened in the labour market, but is this certain? To answer this question, the activity rate of women in selected age groups 25-34 and 35-44 was checked.

The study was narrowed to these age groups for two reasons: (1) demographic changes have shifted the highest female fertility levels from the 20-24 age group to the 25-29 age group. They have also resulted in a significant increase in fertility in 
the 30-34 age group, which is mainly due to the introduction of "postponed" first births, while in the 35-44 age group, subsequent births occur (Stańczak, Stelmach, and Urbanowicz, 2015); (2) from the Central Statistical Office data on live births during a single maternal year, it appears that in 2017 and 2018 women from the 25-34 age group accounted for $66.51 \%$ of births in 2017 and $65.94 \%$ in 2018 , respectively, and nearly all the remaining births were from women in the next age group. Thus in these groups there was potentially the largest number of women entitled to parental benefit for children up to 18 years of age and, thus, to a 500+ benefit. In following age groups a relatively small number of women [BDL] have this right.

Figure 2 shows that until 2015, the economic activity rate (K) in the studied age groups oscillated (increased and decreased) between $78 \%$ and $82.5 \%$, which was associated with the improving economic situation and falling unemployment. Since 2016, this ratio decreased in the age group 25-34 by a total of $4.2 \mathrm{pp}$ (i.e. fell even below the 2010 level), and in the 35-44 age group, by $1.5 \mathrm{pp}$ over four years. At the same time, it can be noted that in the first year of the 500+ benefit, the greater change in the coefficient took place in the 35-44 age group, i.e. probably not among women with several children. A smaller change was seen in the first group because the income criterion for the first child operated in it. In addition, after the ratio decreased in 2016-2017, it then increased temporarily in 2018, followed by a further decline in the following year after the abolition of the income criterion for the first child. The slight increase in 2018 could be due to two factors, namely, that women who gave birth to their first child in 2017 and did not meet the income criterion for a family member, returned to work after maternity leave. The reduction in the economic activity rate (K) again occurred in 2019 and this time it was higher in the 25-34 age group, i.e. probably women with one child. It can, therefore, be said that the introduction of the $500+$ benefit has reduced the economic activity of women in the analysed age groups.

In order to approximate this phenomenon, the causes of women's inactivity were analysed. The CSO [2016] includes discouragement caused by the ineffectiveness of looking for a job, education, supplementing qualifications, family and home responsibilities, retirement, illness, disability, and others (Figure 3).

In 2010-2015, among the reasons for professional inactivity, only the percentage of women retiring increased. This was related to the aging of the population and the retirement of the from the post-war baby boom, while the share of other reasons for deactivation was decreasing. It is important that the share of discouragement resulting from the ineffectiveness of seeking a job decreased because this means an improvement in the labour market. Therefore, it cannot be said that women had no alternative choosing family responsibilities because at that time the demand for work was growing. Since 2016, there has been an increase in the percentage of professional inactivity caused by family and home-related responsibilities $(2 \%)$, which is probably related to the introduction of the $500+$ benefit. This problem is more accurately illustrated by data on the number of economically inactive women due to family and home-related responsibilities (Table 1). 


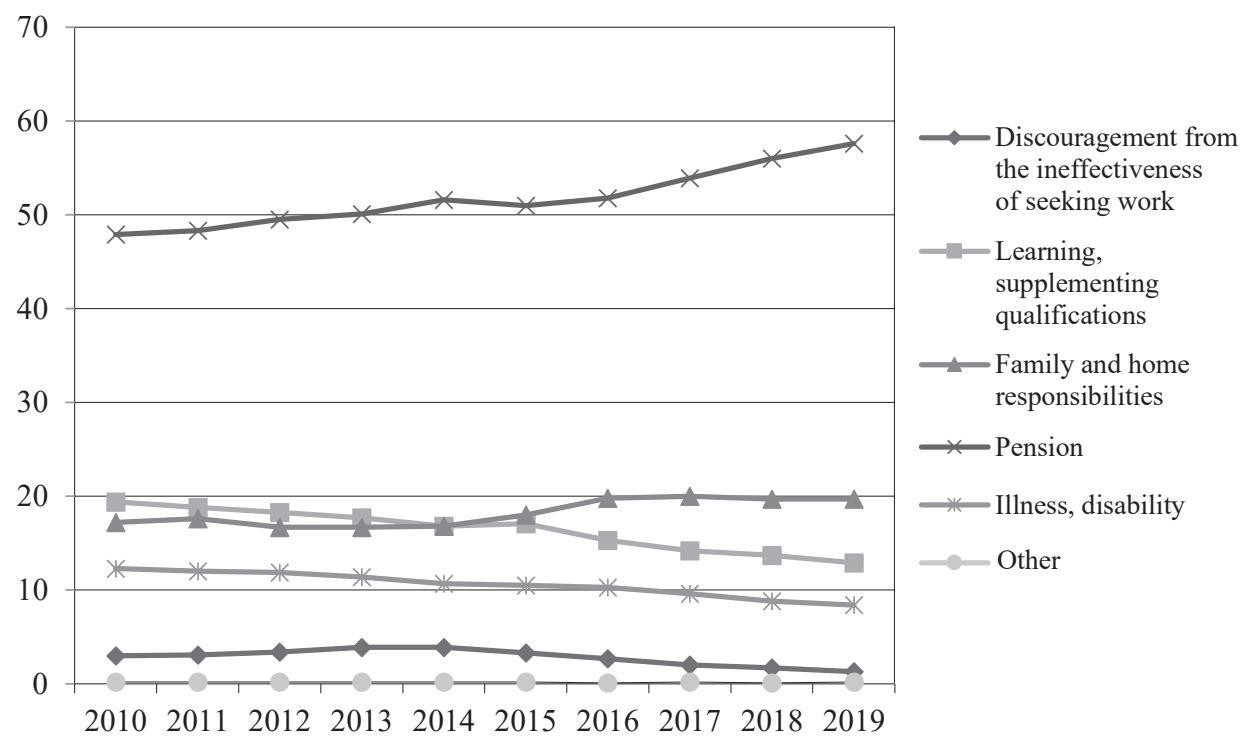

Fig. 3. Occupational inactivity of women by cause (\%)

Source: study based on (GUS, 2016).

Table 1. Occupational inactivity of women due to family and home-related duties in the fourth quarters of 2010-2019 (thousands)

\begin{tabular}{|l|l|l|l|l|l|l|l|l|l|l|}
\hline \multicolumn{1}{|c|}{ Years } & 2010 & 2011 & 2012 & 2013 & 2014 & 2015 & 2016 & 2017 & 2018 & 2019 \\
\hline $\begin{array}{l}\text { Family and } \\
\text { household } \\
\text { responsibilities }\end{array}$ & 1422 & 1447 & 1345 & 1335 & 1360 & 1453 & 1600 & 1626 & 1596 & 1603 \\
\hline
\end{tabular}

Source: study based on (GUS, 2016).

From 2010 to 2014 the number of economically inactive women due to family and home-related responsibilities decreased by a total of 62,000 . These women entered the labour market, because - as already mentioned - the number of women discouraged by the ineffectiveness of looking for a job declined and unemployment decreased, which is discussed later in the article. However, from 2015 this number began to increase, reaching the highest level in 2016. Initially, however, this increase was probably the result of the reproductive activity of women from the last baby boomers of the 1980s and 90s, who then began to give birth and use child maternity/ parental leaveI as seen from CSO data. This may confirm the temporary reduction in the number of economically inactive women in 2018 - returning to work after three years of leave. This resulted in the 500+ benefit, causing an increase in the number of 
women who were inactive due to family responsibilities. In total, over five years, the number of economically inactive women has increased by 150,000 for this reason, which means it can be assumed that many women left their jobs voluntarily without adding to the unemployed numbers.

There are two reasons for this: women in Poland have, on average, a lower income than men because they earn less than men (about $18 \%$ on average), and their time commitment to care responsibilities is higher (on average twice) (Magda, Brzeziński, Chłon-Dominczak, Myck, and Tyrowicz, 2018; Magda, Kiełczewska, and Brandt, 2018). The effect of limiting activity in the labour market can be particularly strong among low-income families and women with low levels of education, which results in their receiving low wages. Comparing the effort of earning a salary with the amount of income from the 500+ benefit and not spending money on childcare when they are at home, they chose what is more useful for them - they left their jobs, therefore making the classic economic choice - behave like homo economicus - choosing what is attractive to them.

Professional activity determines the supply of labour, therefore employment was not examined according to different criteria. This started with the number of women employed by education (Figure 4).

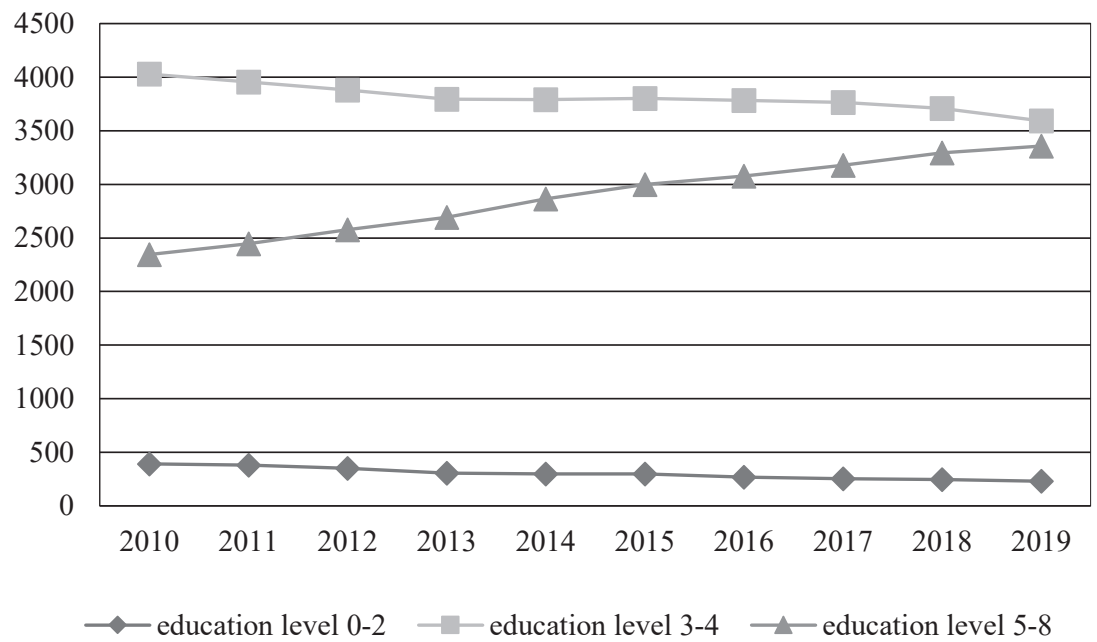

Fig. 4. Number of women employed by education in the age of 20-64 (thousand)

Source: study based on Eurostat.

The number of employed women has increased above the period considered as higher education (level 5-8), which reflects the nature of the demand for work in the knowledge-based economy that Poland aspires to. Even after the introduction of the $500+$ benefit, the trend in this group has not changed, quite the opposite in fact, i.e. there was a further increase in the number of employed women (by 359,000 
in total in four years $\left.{ }^{3}\right)$. Therefore, in this group, the benefit was an incentive to increase their income (and thus the standard of living of the family) through work. The opposite changes occurred in the number of employed women in other groups, where the downward trend has been continuing since 2010, which is related to the change in the structure of the economy and the demand for work. In 2016 - after the introduction of the 500+ benefit - the decline continued. By 2015, the number of employed women with secondary education (level 3-4) decreased by 226,000, and for primary and basic education (level 0-2), by 95,000 (in total, 321,000). In 2016-2019 , by 210,000 and 67,000 , respectively (in total, 277,000). The trend of these changes confirms the earlier statement and the results of other studies showing that women with lower education and wages usually left their jobs, and for them, income from benefits is more attractive. To sum up - the difference between the number of women who started work and resigned after the introduction of the benefit was 82,000 .

Taking the above into account, the number of employees by sex was checked, with the specification of women aged 25-54 (Figure 5). In 2010-2015, the total number of employed women and men increased by 179,000 and 133,000, respectively, with the number of employed men always being higher. Since 2016, the numbers of employedmen and women have decreased, by 242,000 and 209,000, respectively. No changes in the employment of men were expected (and by no means this size) hence this may apply to men with lower education and wages who began to live at the expense of children receiving benefits. It is difficult to talk about unemployment when there was a shortage of labour force supply in the economy as a whole. In total, the number of employees dropped by 451,000 over four years. On the other hand, the number of employed women aged 25-54 was constantly decreasing; in the period $2010-2015$ by 71,000 , and in $2016-2019$ by 188,000 , (2.6 times more than before), which suggests the negative impact of the $500+$ benefit. In total, over the past nine years the number of employed women in this age group dropped by 259,000 . Therefore, it can be said that this statement confirms the reduction in female labour force supply.

Changes in the employment of $\mathrm{K}$ and $\mathrm{M}$ affected the total number of employees, which increased until 2014 and then began to decrease. In total, from 2016 to 2019, it decreased by 293,000 which confirms choosing the benefit instead of work. Despite these unfavorable changes in the last four years, in 2019 the number of employees in the economy aged 20-64 was 4,862,000, (41\%) higher than in 2010, which was associated with the improvement of the economic situation, reduction of unemployment, and the increase of the global labour force supply due to the migration of foreigners.

The study was supplemented with an analysis of the employment rate, which in the examined period, both in total and for both sexes, showed an upward trend (Figure 6). The employment rate of (K) has always been lower than the employment

\footnotetext{
${ }^{3}$ Own calculations based on Eurostat data.
} 


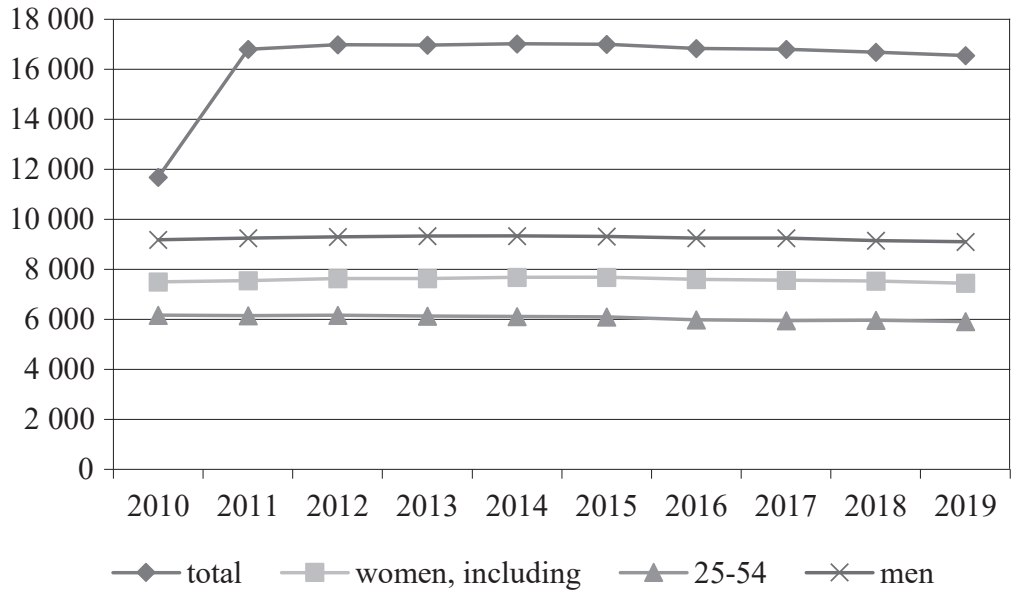

Fig. 5. Number of employed in the age of 20-64 (thousands)

Source: study based on Eurostat.

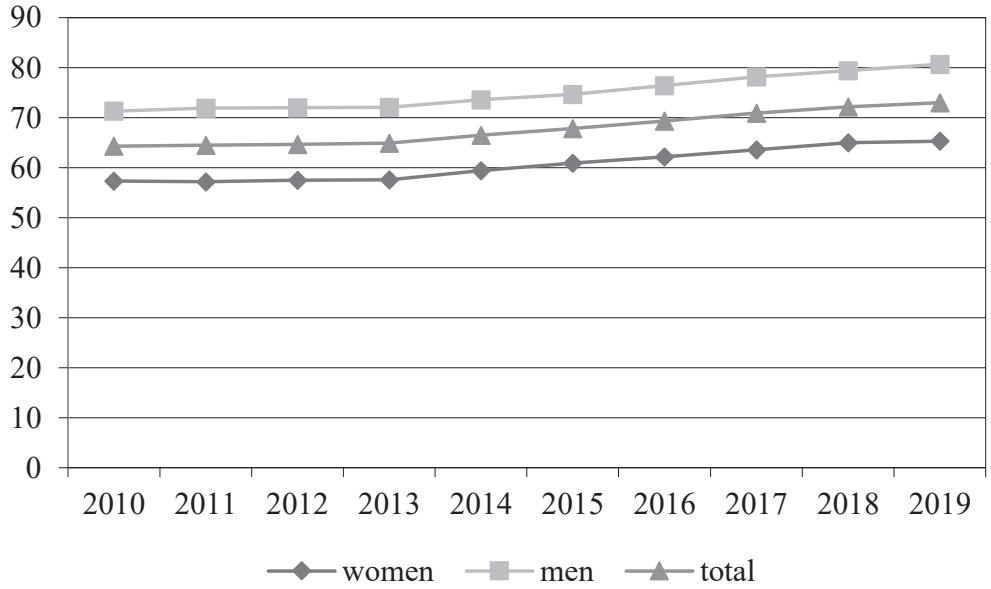

Fig. 6. Employment rate in Poland by sex in age group 20-64

Source: study based on Eurostat.

rate of $(\mathrm{M})$, and the difference between these indicators increased from $14 \mathrm{pp}$ in 2010 to $15.4 \mathrm{pp}$ in 2019. While, until 2016, this difference fluctuated on a similar level (on average 14.2\%), it has increased by $1.2 \mathrm{pp}$ in 2017, over three years which, during both good economic times and scarcity of labour force resources, may suggest voluntary withdrawal from the labour market. At the same time, the 
employment rate of $(\mathrm{K})$ was less dynamic, increasing by $8 \mathrm{pp}$ in nine years, and for (M) by $9.4 \mathrm{pp}$, which indicates that their labour potential was not used. Despite these disproportions in the dynamics and pace of changes in the $\mathrm{K}$ and $\mathrm{M}$ indicators, the overall employment rate in 2019 reached $73 \%$, therefore, it was by 2 pp higher than the level planned by Poland for 2020. Thus, the strategic objective related to the employment rate has been achieved.

The last variable correlated with employment is unemployment. As already mentioned, the number of unemployed, both in total and for women and men, decreased throughout the entire period considered (Figure 7). In 2019, the number of unemployed was $1,051,000(66.2 \%)$ lower than in 2010 , while (K) was 476,000 (64.2\%) lower, and (M) 575,000 (68\%) lower, which was a huge economic success. The unemployment rate in the economy in 2019 was $3.2 \%$, being $6.3 \%$ lower than in 2010. The decrease in the number of unemployed means that women (and, as it turned out, also men) who withdrew from the labour market after starting to receive the benefit 500+, did not increase the registered unemployment figures, only the economically inactive resource.

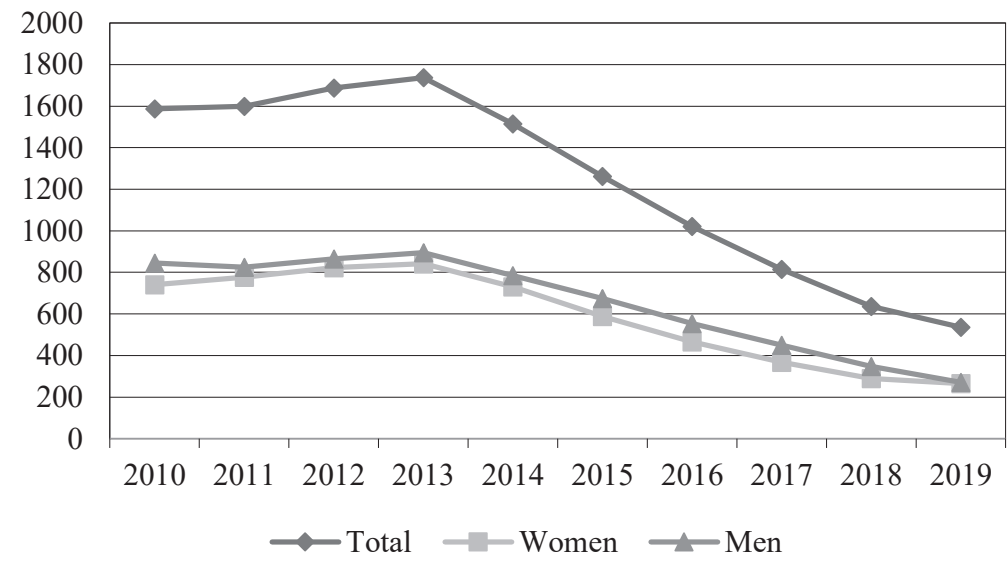

Fig. 7. Number of unemployed aged 20-64 by sex in Poland (thousands)

Source: study based on Eurostat.

In order to supplement the assessment of the impact of the 500+ benefit on the labour market and the economy, and to answer the question posed in the introduction, an attempt was made to estimate the loss in GDP caused by women leaving employment (Table 2).

The available data sources (CSO and reports) provide estimates only and do not include the precise number of women who left work after the introduction of the benefit. Therefore an estimate was made based on the author's own calculations. 
Table 2. Estimation of losses in GDP due to the departure of women from the labour market in 2016-2019

\begin{tabular}{|l|c|c|c|c|}
\hline \multicolumn{1}{|c|}{ Specification } & 2016 & 2017 & 2018 & 2019 \\
\hline $\begin{array}{l}\text { Number of women } \\
\text { who left their jobs } \\
\text { [thousands] }\end{array}$ & $89-147$ & $119-173$ & $143-153$ & $150-242$ \\
\hline $\begin{array}{l}\text { Gross value added } \\
\text { per 1 employed } \\
\text { [PLN] }\end{array}$ & 113875 & 118027 & 112818 & $120.139 *$ \\
\hline $\begin{array}{l}\text { Loss of GDP } \\
\text { [PLN millions] }\end{array}$ & $10134.9-16739.6$ & $14045.2-20418.7$ & $16132.9-17261.2$ & $18020.9-29073.6$ \\
\hline$\%$ of GDP & $0.57-0.94$ & $0.73-1.07$ & $0.80-0.85$ & $0.85-1.38$ \\
\hline
\end{tabular}

* Own estimate.

Source: own calculations based on research and (GUS, 2019).

Depending on the year, the losses on this account range from 0.57 to $1.38 \%$. This is the hidden cost of the Family 500+ parental benefit.

\section{Conclusion}

Based on the research, the following conclusions can be made containing the answers to the questions formulated in the introduction. Namely:

- The participation rate of women in the 25-44 age group decreased after the introduction of the $500+$ benefit, but it increased in other age groups because previously unemployed women returned to the labour market, which is why the aggregate participation rate of women in 2010-2019 increased, resulting in an increase in its level in the economy.

- The number of women inactive due to family and home-related responsibilities increased by 150,000 in the last four years. These women did not increase the number of, or the unemployment rate.

- After the introduction of the benefit, the number of employed women with education at levels 0-2 and 3-4 (in total, 277,000) decreased, which indicates that it was more attractive to them than work. However, the number of employed women with higher education increased significantly (by 359,000).

- After the introduction of the benefit, the total number of employees also decreased; women by 242,000 and men by 209,000 , which caused a decrease in the number of employees in the economy.

Despite the fact that some of the effects of the introduction of the $500+$ benefit were unfavourable, due to the improvement in the economic situation and the increase in demand for work in the period under review, the labour force resources 
so far passive or unemployed have become more active, which altogether resulted in achieving, even with a $2 \%$ surplus, the adopted target of an employment rate of $71 \%$. Therefore, it be said that the situation prior to the pandemic was good.

It is also worth mentioning the estimated loss in GDP as a result of thousands of women leaving paid work, which was set at $0.57-1.38 \%$ depending on the year. In this case, it should be remembered that this is only part of the cost and that the real effects of the 500+ Programme, according to the theory of human capital and investment in such capital, require wider and more comprehensive calculations.

\section{References}

4. urodziny programu ,,Rodzina 500+”. (n.d.). Retrieved June 3, 2020 from https://www.gov.pl/web/ rodzina/4-urodziny-programu-rodzina-500

Bank Danych Lokalnych [GUS]. (n.d.). Retrieved May 14, 2020 from https://bdl.stat.gov.pl/

Dickens, W. T., and Lang, K. (1992). Labor Market Segmentation Theory: Reconsidering The Evidence National Bureau of Economic Research, Cambridge, June.

Doeringer, P., and Piore, M. (1971). Internal labor markets and manpower adjustment. New York: DC Heath and Company.

Giddens, A. (2010). Socjologia. Warszawa: Wydawnictwo Naukowe PWN.

GUS. (2016). Aktywność ekonomiczna ludności Polski w latach 2010-2019. Warszawa.

GUS. (2019). Rocznik Statystyczny. Warszawa.

Haponiuk, M. (2014). Sytuacja kobiet na rynku pracy w Polsce. Analiza, (2).

Hrynkiewicz, J., Witkowski J., and Potrykowska A. (Ed.). (2018). Demograficzne i systemowe uwarunkowania polityki zatrudnienia (pp. 68-69). Warszawa: Rządowa Rada Ludnościowa.

Jarmołowicz, W., and Knapińska, M. (2011). Współczesne teorie rynku pracy a mobilność i przepływy pracowników w dobie globalizacji. Zeszyty Naukowe PTE, (9), 123-144.

Knapińska, M. (2009). Przeplywy pracowników. Wyniki wyszukiwania w świetle makro- i mikroekonomicznych teorii rynku pracy - mikroekonomia. Retrieved May 20, 2020 from http://mikroekonomia.net/system/publication_files/89/original/16.pdf?1314879895

Kryńska, E., 2000, Mobilność zasobów pracy w wybranych teoriach rynku pracy. In: E. Kryńska (Ed.) Mobilność zasobów pracy. Warszawa: Instytut Pracy i Spraw Socjalnych.

Kotowska, I. E., Sztanderska, U., and Wóycicka, I. (Ed.). (2007). Między domem a praca: rekomendacje. Warszawa: Scholar.

Magda, I., Brzeziński, M., Chłon-Dominczak, A., Myck, M., and Tyrowicz, J. (2018). „Rodzina 500+” - ocena programu i propozycje zmian. IBS, 10-11.

Magda, I., Kiełczewska, A., and Brandt, N. (2018). The "Family 500+" Child Allowance and Female Labour Supply in Poland (IBS Working Paper, No 01).

OECD. (2016). Family Database, Maternal employment rates by partnership status and level of education. Retrieved June 1, 2020 from http://www.oecd.org/els/soc/LMF_1_3_Maternal_employment_by_partnership_status.pdf (1.06.2020)

Piore, M. (2002). Thirty years later: internal labor markets, flexibility and the new economy. Journal of Management and Governance, 6, 271-279.

Podręcznik dla samorządów - przyznawanie świadczeń wychowawczych Program , Rodzina 500 +”. 2017. Ministerstwo Rodziny Pracy i Polityki Społecznej. Retrieved June 3, 2020 from https:// www.gov.pl/web/rodzina/materialy-do-pobrania 
Raport. (2016). Praca i przedsiębiorczość kobiet (p. 7-9). Coca-Cola Poland Services.

Reich, M., Gordon, D. M., and Edwards, R. C. (1973). A theory of labor market segmentation. The American Economic Review, 63(2) (Papers and Proceedings of the Eighty-fifth Annual Meeting of the American Economic Association, May, pp. 359-365).

Rękas, M. (2013). Kobiety-matki i ich powrót na rynek pracy po urodzeniu dziecka w wynikach badań. Studia Ekonomiczne. Uniwersytet Ekonomiczny w Katowicach, (161), 122-131.

Samuelson, P. A., Nordhaus, W. D., 2020, Economics. Poznań: Rebis.

Stańczak, J., Stelmach, K., and Urbanowicz, M. (2015). Małżeństwa i urodzenia w Polsce. Retrieved June 1, 2020 from https://ec.europa.eu/eurostat/statistics-exlained/index.php?title=Archive: Marriages_and_births_in_Poland/pl\&oldid=265879\#Wzrost_wieku_kobiet_rodz.C4.85cych_dziecko

Ustawa z dnia 11 lutego 2016 r. o pomocy państwa w wychowywaniu dzieci (Dz. U., poz. 195)

Working Papers no. 4087, National Bureau of Economic Research, Cambridge, Retrived June 1, 2020 from https://econpapers.repec.org/paper/nbrnberwo/4087.htm

\section{PROGRAM RODZINA 500+ A CEL Z OBSZARU RYNKU PRACY STRATEGII EUROPA 2020}

Streszczenie: Istnieją ogromne kontrowersje wokół zagadnienia oddziaływania świadczenia 500+ na rynek pracy w Polsce, zwłaszcza na aktywność zawodową kobiet. Skutki w tym zakresie są istotone nie tylko dla kraju, ale też dla Unii Europejskiej, gdyż determinują zrealizowanie celu strategii Europa 2020 związanego z zatrudnieniem. Celem głównym artykułu jest odpowiedź na pytanie, jak świadczenie 500+ wpływa na podaż pracy kobiet i realizację celu strategii Europa 2020 związanego z zatrudnieniem. Cele szczegółowe to: (1) Jakie były cele polskiego rządu w obszarze rynku pracy na początku realizacji strategii unijnej, a jakie są obecnie w Strategii Odpowiedzialnego Rozwoju (SOR)? (2) Jak kształtowała się dynamika podaży kobiet na tle zmian na rynku pracy? (3) Jakie znaczenie dla trendów na rynku pracy ma program 500+? (4) Jaką stratę (i czy w ogóle) dla gospodarki wygenerowało zmniejszenie zatrudnienia kobiet? Przedmiotem badań jest podaż pracy kobiet/zatrudnienie, a podmiotem badań polska gospodarka. Okres badawczy to lata 2010-2019, ze szczególnym uwzględnieniem okresu po wprowadzeniu świadczenia w $2016 \mathrm{r}$. Z badań wynika, że niekorzystne zmiany w podaży pracy kobiet, spowodowane świadczeniem $500+$, zostały zniwelowane powrotem na rynek pracy osób dotychczas bezrobotnych lub biernych zawodowo. Dzięki temu cel strategiczny związany z zatrudnienim został zrealizowany.

Słowa kluczowe: rynek pracy, kobiety, Program Rodzina 500+, strategia Europa 2020. 